Int. J. Morphol.,

32(2):426-431, 2014.

\title{
Morphological Alterations in Mouse Placenta Induced by Diazepam
}

\author{
Alteraciones Morfológicas Inducidas en la Placenta de Ratón por Diazepam
}

\author{
María Cristina Márquez-Orozco*; María Verónica Gasca-Ramírez*; \\ Graciela de la Fuente-Juárez* \& Amalia Márquez-Orozco*
}

\begin{abstract}
MÁrQUEZ-OROZCO, M. C.; GASCA-RAMírez, M. V.; DE LA FUENTE-JUÁREZ, G. \& MÁRQUEZ-OROZCO, A. Morphological alterations in mouse placenta induced by diazepam. Int. J. Morphol., 32(2):426-431, 2014.

SUMMARY: Diazepam (DZ) is a benzodiazepine that belongs to the group of minor tranquilizers with myo-relaxing and anticonvulsant properties. DZ and its metabolites cross the placental barrier in human, monkey, hamster, and mouse, and accumulate in the placenta. Our aim was to investigate, through histological techniques, and semifine sections if DZ induces morphological changes in the placenta. Twenty female mice of the ICR strain were distributed randomly in two groups. One group (DZ) was treated from days 6 to 17 of gestation with a single daily subcutaneous (sc) dose of DZ of $2.7 \mathrm{mg} / \mathrm{kg} /$ (bw); the second, control group (C) was treated with saline solution. All females (10 DZ and $10 \mathrm{C}$ ) were killed by decapitation. Placentas were extracted and fixed in phosphates-buffered $10 \%$ formaldehyde, $\mathrm{pH} 7.3$, dehydrated, and embedded in paraffin to obtain $3 \mu \mathrm{m}$ thick sections or fixed in $2.5 \%$ glutaraldehyde, post-fixed in $1 \% \mathrm{OsO}_{4}$, embedded in epoxy resin. Histological sections were stained with hematoxylin-eosin or Weigert's iron hematoxylin. Semifine sections were stained with toluidine blue. All sections were observed under comparative light microscopy. The DZ-group showed thinned placental barrier with multiple vacuoles. Nuclei of trophoblast cells (TCs) and trophoblast giant cells (TGCs) presented heterochromatin in coarse granules, atypically distributed in the karyolymph and conspicuous nucleoli. The cytoplasm of the TGCs was vacuolated and chromatin had a similar appearance to that observed in TCs. The total area of the placental barrier was measured in $\mu \mathrm{m}^{2} / \mu \mathrm{m}^{2}$; the $\operatorname{area}$ in the DZ group was reduced as compared with the $\mathrm{C}$ group $(\mathrm{P}<0.001)$. Alterations of TGCs could be due to an interaction of DZ with peripheral type benzodiazepine receptors involved in progesterone biosynthesis. Administration of DZ in mice alters the placental barrier and TGCs which could affect their physiology and causes teratogenic effects on the ovary and testis involved in steroid hormones biosynthesis.
\end{abstract}

KEY WORDS: Benzodiazepine; Diazepam; Mouse; Placenta; Histology.

\section{INTRODUCTION}

Diazepam (DZ) is a benzodiazepine that exerts anxiolytic, sedative, anticonvulsant, anti-anxiety, hypnotic and amnestic effects. Most of these effects are thought to result from a facilitation of the action of gamma amino butyric acid o GABA, an inhibitory neurotransmitter in the central nervous system (Feldman et al., 1997). Due to these properties it is used in gyneco-obstetrics, in cases of imminent abortion premature activity of the uterus, placenta previa, eclampsia and pre-eclampsia, as well as in patients with psychiatric disorders during pregnancy and labor. Women with various psychiatric disorders take psychotropic medication during pregnancy either intentionally or by accident especially in the first trimester, as well as during the perinatal period, lactation, and nursing (Harding \& Timko, 2014), without considering the damage they can cau- se to their offspring DZ is a benzodiazepine used as drug of abuse although it only exerts mild to moderate euphoria effects in recreational drug users (Cole \& Chiarello, 1990).

DZ is highly bound to plasma proteins (98\%). DZ and its metabolites cross the placental barrier in humans, monkeys, mice, and hamsters, they circulate in greater amounts in fetal than in maternal blood, and they accumulate in fetal tissues and in the placenta. DZ also been found in breast milk at concentrations approximately one tenth of those found in human maternal plasma, where it remains for 3 to 9 days post-partum. DZ is slowly eliminated through the urinary tract. The initial distribution phase has a halflife of approximately 1 hour although it may range up to $>3$ hours (Mandelli et al., 1975). 
There are many risks associated with the use of benzodiazepines during pregnancy. Reports include neonatal respiratory and neurological depression, Apgar test of 5 to 6 , during the first minute after birth, flaccidity, hypotonia (floppy appearance of the muscles), sucking difficulty, feeble cry, hypothermia, and hyporeflexia observed in newborns whose mothers were treated with DZ during labor (Flowers et al., 1969). Other manifestations include alterations in cardiac rhythm (Scher et al., 1972), onset of respiration is retarded and is shallow and irregular, requiring sometimes tracheal intubations, body temperature is poorly regulated, and hypotonia is also more severe; these symptoms can last up to 10 days after birth (Cree et al., 1973). Congenital malformation and teratogenic effects have been reported in newborns from mothers consuming benzodiazepines Laegried et al. (1989), identified a syndrome, benzodiazepine embryofetophathy related to in utero benzodiazepine exposure: it resembles, to some extent, the fetal alcohol syndrome (Laegried et al., 1990).

Data from our own studies have shown that mouse fetuses (CD-1 strain) from mothers treated with DZ at doses of $2.7 \mathrm{mg} / \mathrm{kg} /$ (bw) present histological changes in tibial ossification, testes, retina, cerebellum (De la Fuente-Juárez et al., 1988; Ramos-Ávila et al., 1993; Márquez-Orozco et al., 1983, 1992; Andrada-Martínez et al., 1993).

Based on the aforementioned data, we decided to determine, through histological techniques, whether the placenta of mouse fetuses (ICR strain) of 18 days gestation is altered by DZ deposited in their tissues, subsequent to administration of the drug to their mothers from day 6 to 17 of gestation, at a daily single subcutaneous (sc) dose of $2.7 \mathrm{mg} / \mathrm{kg} /(\mathrm{bw})$.

\section{MATERIAL AND METHOD}

Fifty female and ten male mice of the ICR strain, 2 months old, with a body weight of $25 \pm 2 \mathrm{~g}$ and $32 \pm 2 \mathrm{~g}$, respectively, were used. Animals were mated at a proportion of 3:1, between 5:00 and 5:30 a.m. The females were then separated and inspected for the presence of vaginal plug. Those with positive results were randomly distributed in a $\mathrm{DZ}$ and a $\mathrm{C}$ group, allowing gestation to continue normally until the 6th day, at which treatment was begun.

The DZ group received daily single sc doses of 2.7 $\mathrm{mg} / \mathrm{kg} /$ (bw) of DZ until day 17 and the C group was treated with equivalent volumes of saline solution. At day 18 of gestation, all (10 C and $10 \mathrm{DZ})$ females were killed by decapitation. Abdominal laparotomy was performed, the uterus was resected to obtain the fetuses and the placentas, which were fixed in $10 \%$ formaldehyde, buffered with phosphates at a $\mathrm{pH}$ of 7.3. Then, they were dehydrated and embedded in paraffin to obtain $3 \mu \mathrm{m}$ thick sections, that were stained with hematoxylin-eosin and Weigert's iron hematoxylin. Other placentas were fixed in $2.5 \%$ glutaraldehyde, post-fixed in $1 \% \mathrm{OsO}_{4}$, embedded in epoxy resin. Semifine sections were stained with toluidine blue. Histological and semifine sections were observed under light microscopy.

Assessment of the area of the placental barrier in the histological sections was done with an electronic digital summagraphic model 10-1-OTR-1414TT. Results were subjected to statistical analysis by means of Student's $t$ test.

\section{RESULTS}

Placentas of the fetuses from the group treated with DZ showed in the histological and semifine sections that the chorial vessels and the intervillous spaces were dilated and more profuse than in the $\mathrm{C}$ group. Their cytoplasm had a spongy aspect, showing a great amount of small spaces resembling vacuoles, distributed among the trophoblast layers of the placental barrier. These spaces could be identified, with low or high magnifications, as clear areas, providing the placenta with a different appearance than that shown in the $\mathrm{C}$ group (Figs. 1-4). The placenta barrier tissues and trophoblast cells (TCs) stained with toluidine blue also revealed numerous grains with a higher staining affinity (Fig. 5). The $\mathrm{C}$ group presented these vacuole-like spaces in some TCs (Fig. 6).

The nuclei of the TCs of the placental barrier, as well as those of the endothelial cells, were more irregular in shape and size in the DZ group. Heterochromatine was often found to form large clumps, atypically distributed in the karyolymph, and showed a higher staining affinity (Figs. 1-6).

The TGCs of the fetuses pretreated with DZ were exuberant, and their cytoplasm showed membranous elements of thick networks and numerous large vacuoles, containing scattered reticular material in a slightly stained matrix. Their nuclei showed an irregular contour, containing thick chromatin granules dispersed in the karyolymph, which was clear, or located close to the cell membrane. As opposed, in the $\mathrm{C}$ group, the TGCs presented less and smaller vacuoles. The nuclei and heterochromatin showed normal size and stain affinity (Figs. 7, and 8). 


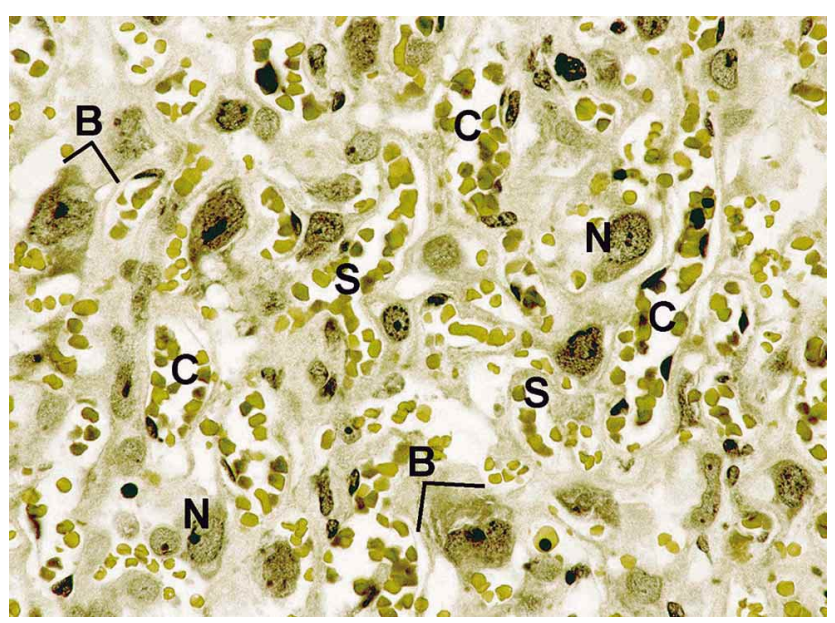

Fig. 1. Placenta from a fetus of the $\mathrm{C}$ group. The placental barrier (B) shows normal appearance of intervillous spaces (S), chorial vessels $(\mathrm{C})$, and nuclei of trophoblast cells $(\mathrm{N})$. Modified Weigert's ferric hematoxylin. Original magnification 370X.

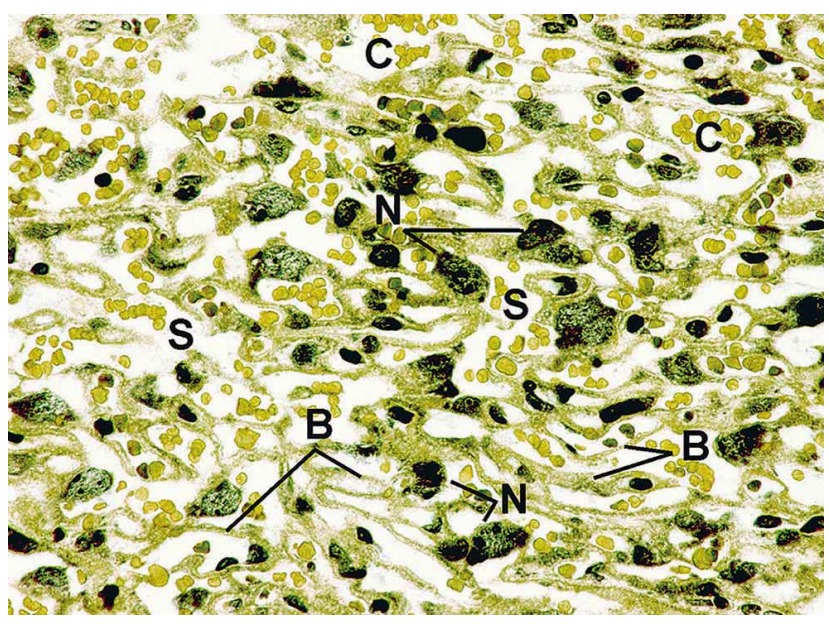

Fig. 2. Placenta from a fetus of the DZ group. Notice the dilatation and the increased number of intervillous spaces (S) and chorial vessels (C), as well as the thinned placental barrier (B), and the nuclei of the trophoblast cells $(\mathrm{N})$. Modified Weigert's ferric hematoxylin. Original magnification 370X.

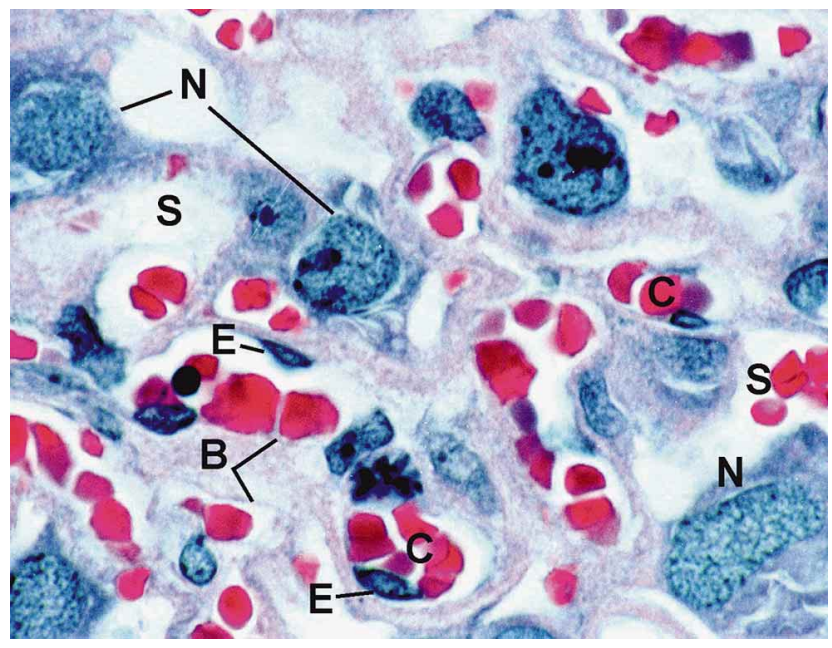

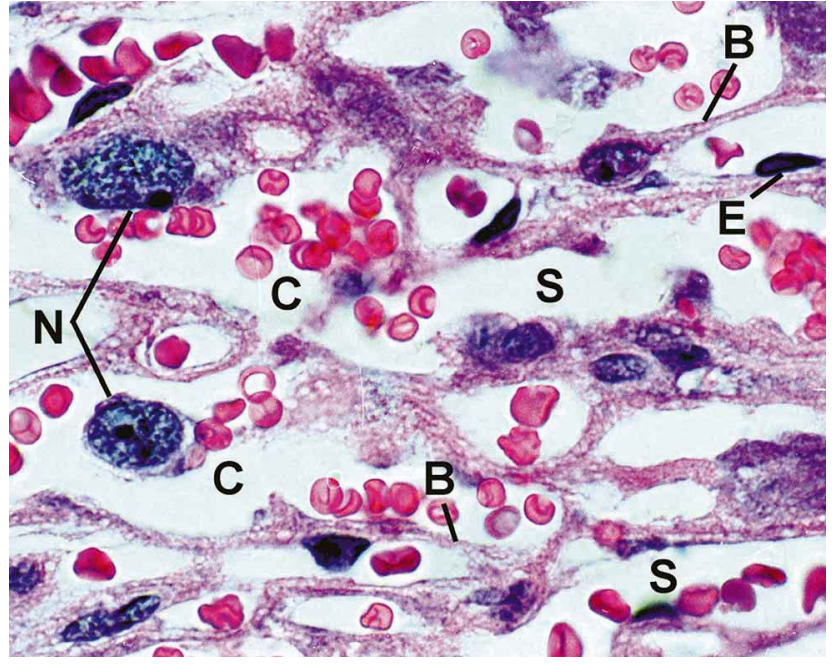

Fig. 4. Placenta from a fetus of the DZ group. The placental barrier (B) shows multiple vacuoles (V). Chorial vessels (C), intervillous space $(\mathrm{S})$, nuclei of trophoblast cells $(\mathrm{N})$, coarse chromatin granules and nuclei of endothelial cells (E) are easily identified. Hematoxylin-eosin. Original magnification 930X.

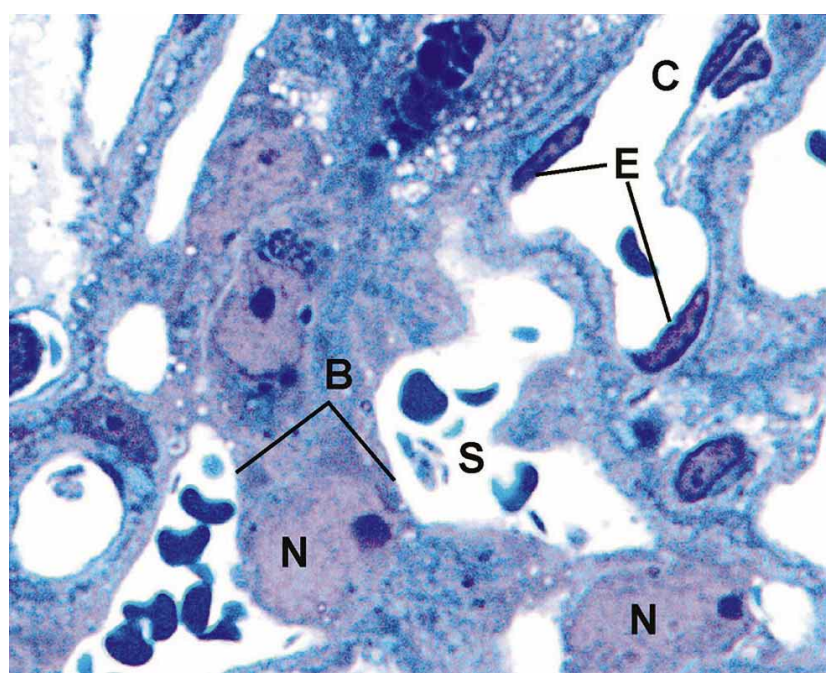

Fig. 5. Placenta from a fetus of the $\mathrm{C}$ group showing normal structure of placenta barrier (B), chorial vessels (C), intervillous space (S), nuclei (N) of trophoblast cells, and nuclei of endothelial cells (E). Toluidine blue. Original magnification 930X.

Fig. 3. Placenta from a fetus of the $\mathrm{C}$ group showing normal structure of: placental barrier (B), chorial vessels (C), intervillous space $(\mathrm{S})$, chromatin granules from the nuclei $(\mathrm{N})$ of the trophoblast cells, and nuclei of the endothelial cells (E). Hematoxylin-eosin. Original magnification 930X. 


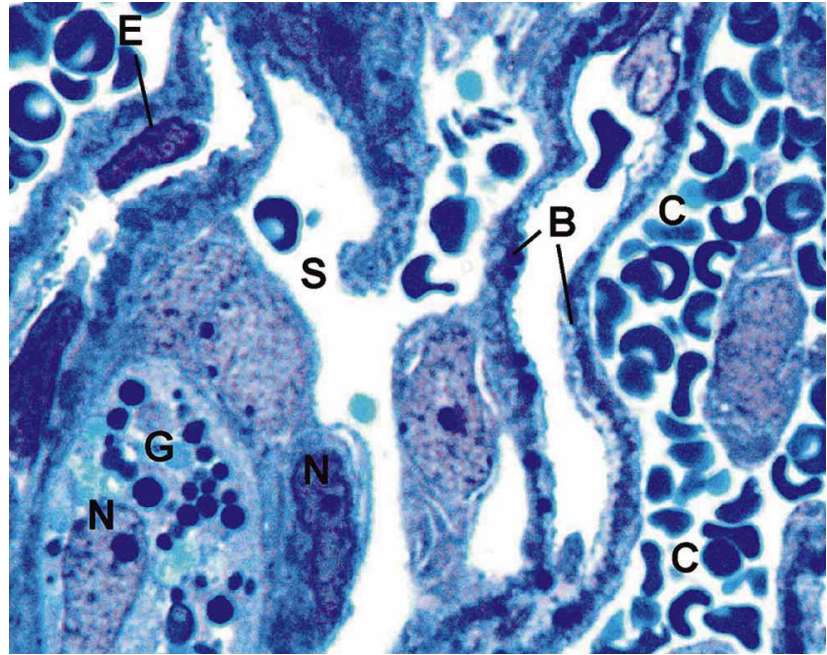

Fig. 6. Placenta from a fetus of the DZ group. The thinned placental barrier (B), and trophoblast cells show numerous hyperstained grains $(\mathrm{G})$. Chorial vessels (C), and intervillous spaces (S) are dilated. Toluidine blue. Original magnification 930X.

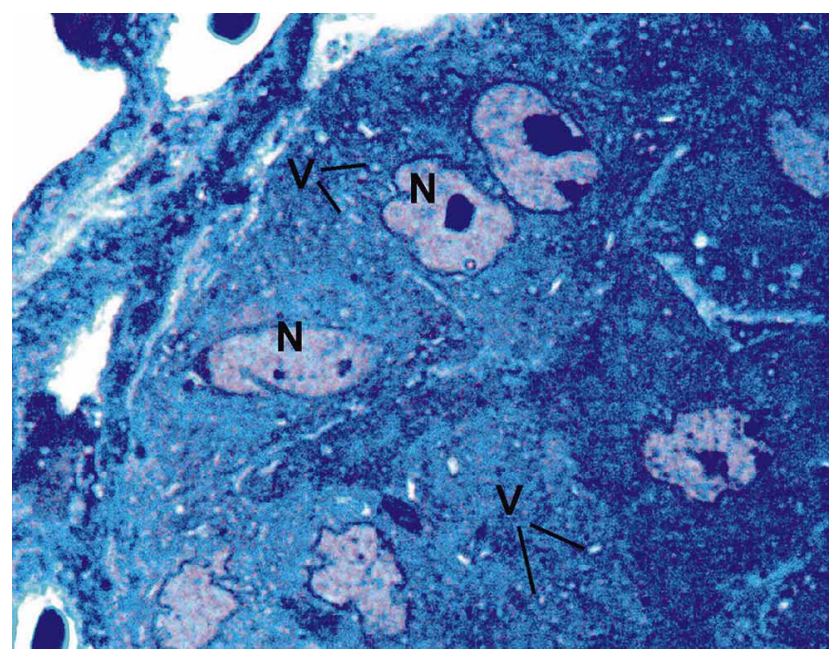

Fig. 7. Placenta from a fetus of the $\mathrm{C}$ group. Compare the size of vacuoles (V), in TGCs with those depicted in Fig. 8. Notice the normal granules of nuclear heterochromatin $(\mathrm{N})$. Toluidine blue. Original magnification 930X.

Analysis of the measurements per square micrometers $\left(\mu \mathrm{m}^{2} \mathrm{~m}^{2}\right)$ from the total area of the placental barrier revealed that this area was reduced in the DZ-treated group $\left(4.83 \times 10^{5} \pm 0.84 \times 10^{5} \mu \mathrm{m}^{2} / \mathrm{mm}^{2}\right)$ as compared with the C group $\left(6.67 \times 10^{5} \pm 0.69 \times 10^{5} \mu \mathrm{m}^{2} / \mathrm{mm}^{2}\right)$. The difference proved to be statistically significant at $\mathrm{P}<0.001$ (Table I, Fig. 9).

\section{DISCUSSION}

The vacuoles observed in the TCs of the placental barrier and in the TGCs could indicate morphological

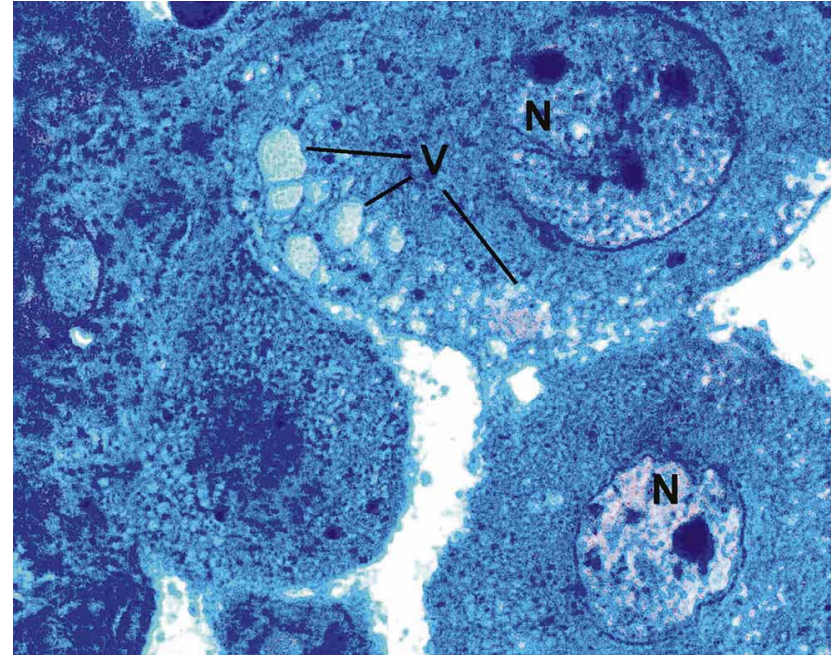

Fig. 8. Placenta from a fetus in the DZ group. Giant trophoblastic cells (B), with large vacuoles, (V); notice the coarse heterochromatin granules in the nuclei $(\mathrm{N})$. Toluidine blue. Original magnification 930X.

Total area of placental barrier in $\mu \mathrm{m}^{2} / \mathrm{mm}^{2}$

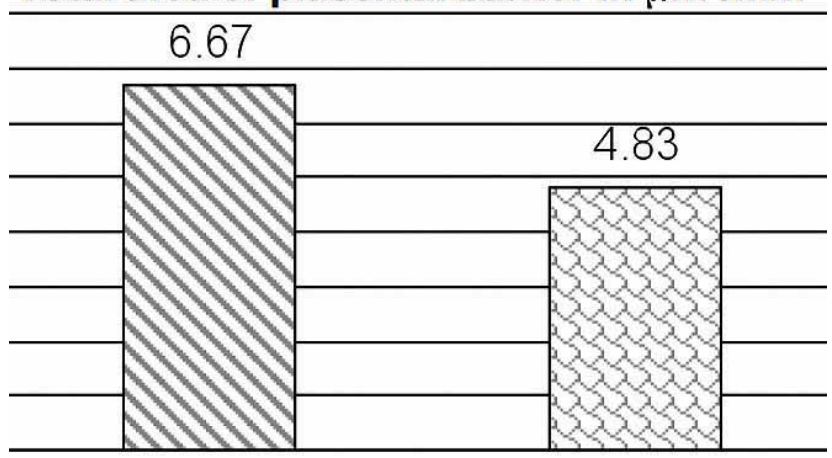

Fig. 9. Total area of placental barrier measured in $\mu \mathrm{m}^{2} / \mathrm{mm}^{2}$ from the DZ and $\mathrm{C}$ groups.

Table I. Total area of placental barrier in $\mu \mathrm{m}^{2} / \mathrm{mm}^{2}$

\begin{tabular}{lcc}
\hline$\overline{\mathbf{A}}$ & $\mathbf{n}$ & Mean \pm SD \\
\hline Control & 50 & $6.67 \times 10^{5 \pm} 0.69 \times 10^{5}$ \\
Diazepam & 50 & $4.83 \times 10^{5 \pm} 0.84 \times 10^{5}$ \\
& & $P<0.001$ \\
\hline
\end{tabular}

alterations of the rough and smooth endoplasmic reticulum and of the Golgi complex, produced by the accumulation of DZ, mainly on the lipids of the third trophoblast layer, in close contact with the endothelium of the chorial vessels. The abundant rough endoplasmic reticulum of the TGCs is probably dilated as a defense against DZ. This drug, by acting as a toxic substance, could trigger the formation of lysosomes, modify protein and glycogen synthesis, and thereby alter ribosomal distribution. All of these alterations could, in turn, account for the thinning of the placental barrier and the dilatation of the chorial vessels and of the intervillous spaces. 
Reduction of the rate of cellular multiplication could be related with alterations of $\mathrm{p} 53$ and $\mathrm{Rb}$ required for the differentiation of placental TGCs (Soloveva \& Linzer, 2004), and account for the changes observed, as suggested by the work of Breen \& Stenchever (1970) in human fibroblasts, cultivated in a medium containing DZ at doses of 0.1, 1.0, 10.0, and 20.0 $\mathrm{mg} / \mathrm{ml}$, showing dilation of the rough endoplasmic reticulum, atypical membranous elements, increase in the number of sacs and cisternae of the Golgi complex, electrondense bodies, and decrement in fibrillar matter synthesis. Extra-cellular matrix components in the materno-fetal boundary zone are fibronectine, laminina, and collagen type IV (Saylam et al., 2002). The cytoskeleton of TGCs change during differentiation (Parast et al., 2001) and diazepam alters synthesis of proteins (Nagele et al., 1989).

In the heart, and retina (Márquez-Orozco et al., 1983, 1992) using a transmission electron microscopy, we found dilatation of the rough endoplasmic reticulum with few ribosomes adhered to the walls, as well as large vacuoles surrounded by numerous glycogen granules, and an atypical distribution of the heterochromatin clumps and few interchromatin granules scattered in the karyolymph may be similar observed in the placenta.

The large nuclei, containing large amounts of slightly stained granules, containing chromatin, located close to the membrane, could be explained by the presence of receptors that bind benzodiazepines mainly at the nuclear membrane and the nucleus (Feldman et al.). TGCs are the main endocrine cells of the placenta producing several hormones that regulate the maternal endocrine and immune systems and promote maternal blood flow to the implantation site. Four subtypes of TGCs were identified by their expression of genes that surrounds the implantation site and forms the interface with the maternal deciduas. Histological alterations could be due to changes in gene expressions (Simmons et al., 2007).

Furthermore, toxic events induced by DZ in mouse placenta could be associated with progesterone biotransformation in the placental barrier (Barnea et al., 1989), and with an increased steroid concentration that could lead to a physiological imbalance in steroid synthesis in the placenta. The regulation of genes involved in progesterone biosynthesis include cholesterol side chain cleavage cytochrome P450 (P40scc) and its accessory proteins, steroidogenic acute regulatory protein (StAR) and 3-beta-hydroxysteroid dehydrogenase/isomerase (3-betaHSD) (Sher \& Orly, 2006).

These genes could be altered, and induce histological changes in TGCs and in other trophoblast and endothelial cells. The indirect increase of estrogens, as xenobiotics and as target of the nuclear receptor, could elicit perturbations of chromatin's integrity, which involves chromatin condensation, a step that precedes DNA fragmentation (Moggs \& Orphanides, 2004).

\section{CONCLUSIONS}

DZ accumulated in the placental barrier produces its thinning, probably due to alterations in the cytoplasmic organelles, such as the rough and smooth endoplasmic reticulum and the Golgi complex. This in turn, could be due to chromosome breakage or altered nuclear material caused by the binding of benzodiazepine receptors in the nucleus, in which heterochromatin forms thick atypically distributed granules.

DZ also induces an increase in the number and size of the chorial vessels and of the intervillous spaces that could be related to the thinning of the placental barrier, but could also be due to the diminished rate of cellular multiplication of the trophoblast. DZ leads to an actual reduction $\left(\mu \mathrm{m}^{2} / \mu \mathrm{m}^{2}\right)$ of the placental barrier $(\mathrm{P}<0.001)$. The TGCs present vacuolated cytoplasm and their nuclei show similar chromatin granules as those found in the placental barrier. It is possible that the histological changes observed in the placental tissues cause metabolic alterations that might modify the exchange of substances, normally occurring between mother and fetus. These altered exchanges, added to the direct toxic effects of DZ upon embryonic tissues, could affect prenatal development. Histological alterations could be due to change in genes expression involved in cytoskeleton and steroid synthesis of TGCs and other trophoblast cells.

MÁRQUEZ-OROZCO, M. C.; GASCA-RAMÍREZ, M. V.; DE LA FUENTE-JUÁREZ, G. \& MÁRQUEZ-OROZCO, A. Alteraciones morfológicas inducidas en la placenta de ratón por diazepam. Int. J. Morphol., 32(2):426-431, 2014.

RESUMEN: El diazepam (DZ) es una benzodiazepina que forma parte de los tranquilizantes menores con propiedades miorrelajantes y anticonvulsivantes. El DZ y sus metabolitos atraviesan la barrera placentaria en el humano, mono, hámster y ratón, y se acumula en ésta. Nuestro propósito fue investigar a través de técnicas histológicas y en cortes semifinos si el DZ induce cambios morfológicos en la placenta de ratón. Hembras de ratón de la cepa ICR se distribuyeron al azar en dos grupos. Un grupo (DZ) fue tratado del día 6 al 17 de la gestación con dosis únicas diarias subcutáneas (sc) de DZ de $2.7 \mathrm{mg} / \mathrm{kg}$ (pc); el segundo grupo control (C) se trató con solución salina. Todas las hembras (10 DZ y 10 C), se sacrificaron por decapitación. Se extrajeron las placentas y se fijaron en formaldehido al $10 \%$ amortiguado con fosfatos $\mathrm{pH} 7.3$, se deshidrataron y se incluyeron en parafina para obtener cortes de $3 \mu \mathrm{m}$, o se fijaron en glutaraldehido al $2.5 \%$, se posfijaron en $\mathrm{OsO}_{4}$ al $1 \%$ y se embebieron en resina epóxica. Los cortes histológicos se tiñeron con hematoxilina-eosina o con hematoxilina férrica de Weigert. Los cortes semifinos se tiñeron con azul de toluidina. Todos los cortes se observaron en un microscopio óptico de comparación. El grupo DZ presentó en la barrera placentaria múltiples vacuolas. Los núcleos de las células del trofoblasto y las células 
trofoblásticas gigantes (TGCs) presentaron heterocromatina en grumos gruesos, distribuidos atípicamente en la cariolinfa y nucléolos conspicuos. El citoplasma de las TGCs estaba vacuolizado y la cromatina tenía una apariencia similar a la observada en las células trofoblásticas. El área total de la barrera placentaria se midió en $\mu \mathrm{m}^{2} / \mathrm{mm}^{2}$; el área en el grupo DZ era reducida en comparación del grupo $\mathrm{C}(\mathrm{P}<0.001)$. Las alteraciones de las células trofoblásticas y de las TGCs podrían deberse a la interacción del DZ con los receptores benzodiazepínicos de tipo periférico involucrados en la biosíntesis de progesterona. La administración de DZ en el ratón altera la barrera placentaria y las TGCs que podrían afectar su fisiología y causar efectos teratogénicos en el ovario y el testículo involucrados en la biosíntesis de las hormonas esteroides.

PALABRAS CLAVE: Benzodiazepinas; Diazepam; Placenta; Ratón; Histología.

\section{REFERENCES}

Andrada-Martínez, R.; Márquez-Orozco, M. C. \& Márquez-Orozco, A. Cerebellar histological changes produced by diazepam. Proc. West. Pharmacol. Soc., 36:219-25, 1993 .

Barnea, E. R.; Fares, F. \& Gavish, M. Modulatory action of benzodiazepines on human term placental steroidogenesis in vitro. Moll. Cell. Endocrinol., 64(2):155-9, 1989.

Breen, P. C. \& Stenchever, M. A. Some effects of diazepam on the fine structure of human fibroblasts in tissue culture. Am. J. Obstet. Gynecol., 108(4):520-7, 1970.

Cole, J. O. \& Chiarello, R. J. The benzodiazepines as drugs of abuse. $J$. Psychiatr. Res., 24(Suppl. 2):135-44, 1990.

Cree, J. E.; Meyer, J. \& Hailey, D. M. Diazepam in labour: its metabolism and effect on the clinical condition and thermogenesis of the newborn. Br. Med. J., 4(5887):251-5, 1973.

De la Fuente-Juárez, G.; Márquez-Orozco, M. C. \& Márquez-Orozco, A. Persistent alterations in ossification in adult mice prenatally treated with diazepam. Proc. West. Pharmacol. Soc., 41:187-8, 1988.

Feldman, R. S.; Meyer, J. S. \& Quenzer, L. F. Sedative-hypnotic and anxiolytic drugs. In: Principles of neuropsychopharmacology. Sunderland, Sinauer Associates Inc., 1997.

Flowers, C. E.; Rudolph, A. J. \& Desmond, M. M. Diazepam (valium) as an adjunct in obstetric analgesia. Obstet. Gynecol., 34(1):68-81, 1969.

Harding, J. H. \& Timko, J. V. The use of psychotropic medications during pregnancy and lactation. Global Library of Women's Medicine. 2014. Available in: http://www.glowm.com/section_view/heading/ The $\% 20 \mathrm{Use} \% 20$ of $\% 20 \mathrm{Ps}$ y c hot r o p i c $\% 20$ Medications\%20During\%20Pregnancy\%20and \%20Lactation/item/415

Laegreid, L.; Olegård, R.; Walström, J. \& Conradi, N. Teratogenic effects of benzodiazepine use during pregnancy. J. Pediatr., 114(1):126-31, 1989.

Laegreid, L.; Olegård, R.; Conradi, N.; Hagberg, G.; Wahlström, J. \& Abrahamsson, L. Congenital malformations and maternal consumption of benzodiazepines: a case-control study. Dev. Med. Child. Neurol., 32(5):432-41, 1990.
Mandelli, M.; Morselli, P. L.; Nordio, S.; Pardi, G.; Principi, N.; Sereni, F. \& Tognoni, G. Placental transfer to diazepam and its disposition in the newborn. Clin. Pharmacol. Ther., 17(5):564-72, 1975.

Márquez-Orozco, M. C.; Gazca-Ramirez, M. V. \& Marquez-Orozco, A. Ultrastructural alterations of fetal mice heart produced by treatment with diazepam during gestation. Proc. West. Pharmacol. Soc., 26:83-4, 1983.

Márquez-Orozco, M. C.; Márquez-Orozco, A. \& Gazca-Ramírez, M. V. Ultrastructural changes in photoreceptors and retinal layers of the mouse fetus exposed to diazepam. Proc. West. Pharmacol. Soc., 35:43-6, 1992.

Moggs, J. G. \& Orphanides, G. The role of chromatin in molecular mechanisms of toxicity. Toxicol. Sci., 80(2):218-24, 2004.

Nagele, R. G.; Bush, K. T.; Hunter, E. T.; Kosciuk, M. C. \& Lee, H. Biomechanical basis of diazepam-induced neural tube defects in early chick embryos: a morphometric study. Teratology, 40(1):29-36, 1989.

Parast, M. M.; Aeder, S. \& Sutherland, A. E. Trophoblast giant-cell differentiation involves changes in cytoskeleton and cell motility. Dev. Biol., 230(1):43-60, 2001.

Ramos-Ávila, M.; Márquez-Orozco, M. C. \& Márquez-Orozco,A. Diazepam induced histological changes in the testes of adult mice. Proc. West. Pharmacol. Soc., 36:123-6, 1993.

Saylam, C.; Ozdemir, N.; Itil, I. M.; Sendag, F. \& Terek, M. C. Distribution of fibronectin, laminin and collagen type IV in the materno-fetal boundary zone of the developing mouse placenta. Experimental study. Arch. Gynecol. Obstet., 266(2):83-5, 2002.

Scher, J.; Hailey, D. M. \& Beard, R. W. The effects of diazepam on the fetus. J. Obstet. Gynaecol. Br. Commonw., 79(7):635-8, 1972.

Sher, N. \& Orly, J. Analysis of trophoblast giant cell steroidogenesis in primary cultures. Methods Mol. Med., 122:301-19, 2006.

Simmons, D. G.; Fortier, A. L. \& Cross, J. C. Diverse subtypes and developmental origins of trophoblast giant cells in the mouse placenta. Dev. Biol., 304(2):567-78, 2007.

Soloveva, V. \& Linzer, D. I. Differentiation of placental trophoblast giant cells requires downregulation of p53 and Rb. Placenta, 25(1):29-36, 2004.

\section{Correspondence to: \\ María Cristina Márquez Orozco \\ Departamento de Embriología \\ Facultad de Medicina \\ Universidad Nacional Autónoma de México (UNAM) \\ Mexico 04510 D.F. \\ MÉXICO}

Email: cmarquezor@gmail.com
Received: $20-10-2013$ Accepted: 17-02-2014 